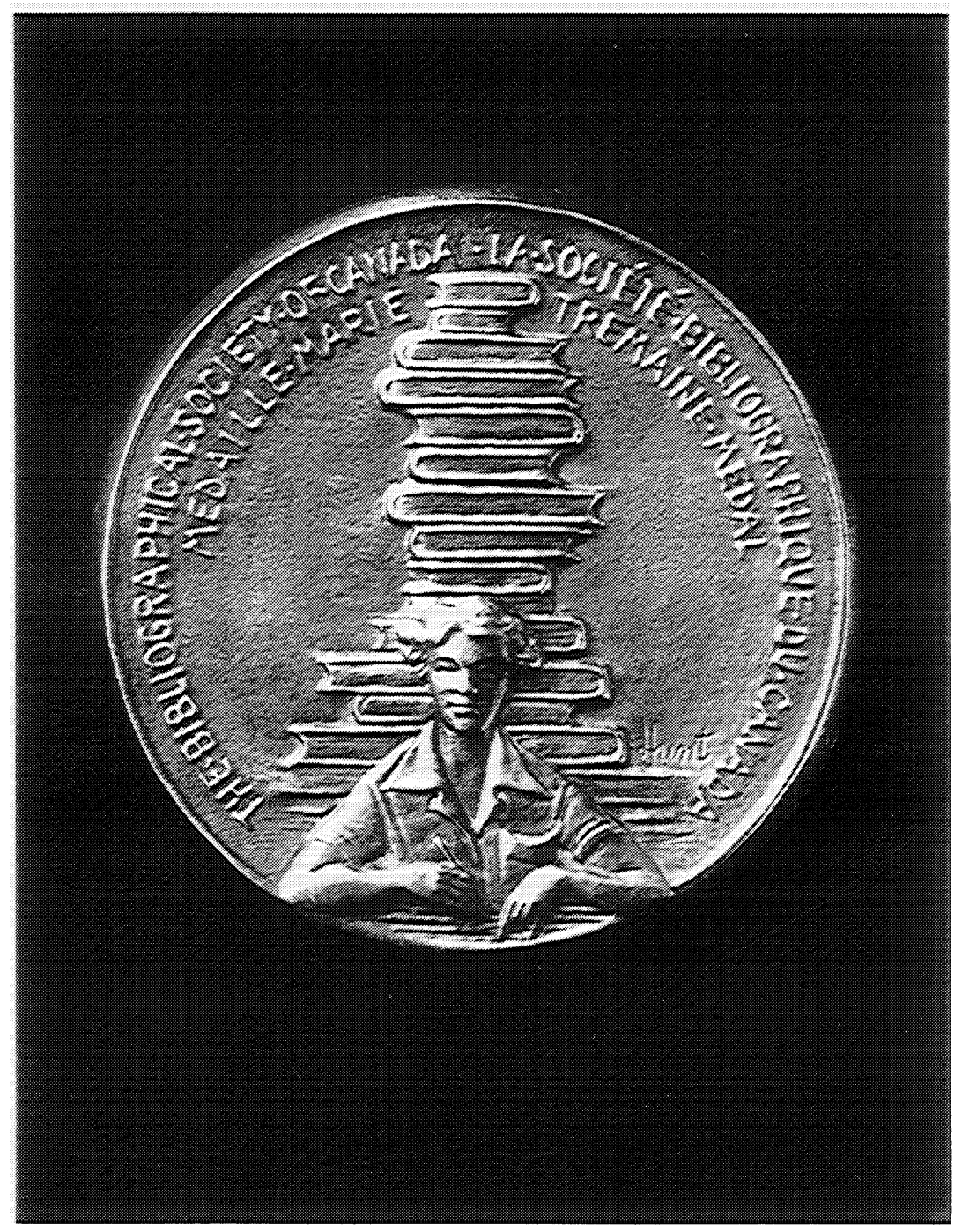

The Marie Tremaine Medal / Médaille Marie Tremaine commissioned from Canadian medallist Dora de Pédery-Hunt. 


\section{The Tremaine Medal \\ La Médaille Marie Tremaine}

The Marie Tremaine Medal is awarded annually by the Bibliographical Society of Canada / Société bibliographique du Canada for outstanding service to Canadian bibliography and for distinguished publication in either English or French in that field, preferably to a member of the Society or to a Canadian citizen. Members of the Council of the Society are not eligible for the award while they are in office. The Tremaine Medal Committee invites nominations for this award.

Previous recipients of the Tremaine Medal have been Marie Tremaine, I970; John Hare and Jean-Pierre Wallot, 1973; Bruce Braden Peel, I975; William F.E. Morley, 1977; Reginald Eyre Watters, 1979; Olga Bernice Bishop, I98 I; Alan F.J. Artibise, I983; Douglas Grant Lochhead, I985; and Agnes Cecilia O’Dea, I987.

La Société bibliographique du Canada / Bibliographical Society of Canada attribue la Médaille Marie Tremaine tous les ans pour services exceptionnels rendus à la cause de la bibliographie canadienne et pour des publications de haute qualité dans ce domaine, soit en français, soit en anglais, préférence étant accordée aux membres de la Société et aux citoyens canadiens. Les membres du Conseil de la Société ne sont pas admissibles pendant les années de leur mandat. La Comité de sélection de la Médaille Marie Tremaine sollicite des candidatures pour le concours.

La Médaille Tremaine a précédemment été décernée à Marie Tremaine, I970; John Hare et Jean-Pierre Wallot, I973; Bruce Braden Peel, I975; William F.E. Morley, 1977; Reginald Eyre Watters, 1979; Olga Bernice Bishop, I98 I; Alan F.J. Artibise, 1983; Douglas Grant Lochhead, 1985; et Agnes Cecilia O’Dea, 1987.

THE I 988 TREMAINE MEDAL

At the Annual Meeting of the Bibliographical Society of Canada / Société bibliographique du Canada on 3 I May I988, in Windsor, Ontario, Sandra Alston was awarded the 1988 Marie Tremaine Medal. In the absence of 
Eric Swanick, the following citation was read by Patricia Stone on behalf of the Society:

Ladies and Gentlemen, The Council of the Bibliographical Society of Canada, on the unanimous recommendation of the Marie Tremaine Medal Committee, has chosen to award this year's Marie Tremaine Medal for Canadian Bibliography to Sandra Alston.

Sandra has twice graduated from the University of Toronto, receiving a B.A. in I97 I and an M.L.S. in I973. For just over a year upon graduation Sandra worked in the Federal Department of Finance Library in Ottawa. In August 1974 she returned to Toronto to the Canadian History Department of the Metropolitan Toronto Library. In late I987 Sandra left Metro to join the University of Toronto library system. In her present position she has responsibilities in both the Robarts Library as book selector for graduate research in Canadiana, and in the Thomas Fisher Rare Book Library, where as Canadian specialist she is responsible both for public service of and cataloguing of the Canadiana collection. Sandra is a member of the major bibliographical societies on this continent and in Great Britain. Since I983 she has been a vice-president of, and for the last few years a leading force in, the Amtmann Circle. We expect to hear more from Sandra in the Bibliographical Society of Canada as she has just been nominated as second vice-president.

However, on this occasion we particularly wish to celebrate Sandra's major project since r983, namely, the four volume second supplement to $A$ Bibliography of Canadiana. Reginald Trotter, writing on the original volume in a 1934 issue of the Canadian Historical Review, stated that '... The work in itself marks an epoch in bibliographical scholarship in the field of Canadiana.' Sandra's second supplement to A Bibliography of Canadiana continues and, may I suggest, expands upon this tradition. Sandra has continued the tradition by following the format of the 'T.P.L.' of I934. She has expanded in the sense that she has adapted the MINISIs software for the production of these volumes.

To date, two volumes have appeared and the final two volumes, one of which will be a cumulative index, are to appear very soon, perhaps have appeared by the time this is read.

Sandra, the work which you have completed in a record amount of time is truly outstanding. It is very fitting that the volumes are dedicated to Marie Tremaine. Thank you, congratulations and best wishes!

The following response was made by Sandra Alston:

I am truly grateful to the Bibliographical Society for paying me the honour 
of awarding me this medal. It really does not belong to me, however, but to the many librarians of the past and in the present who contributed to the Bibliography of Canadiana. The work that we were able to accomplish at the Metropolitan Toronto Library is the result of the energy and the dedication of a number of people. This medal should be dedicated to them, and to the librarian who began the collection - James Bain, whose work was continued and directed by librarians of the calibre of Frances Staton, Harry Campbell and Edith Firth. It was Edith Firth who taught me what it meant to be a collections librarian and I feel very privileged, as do all of the librarians at the Toronto Public Library, and later, the Metropolitan Toronto Library, to have worked with her, and to have had her example of the true scholar-librarian before me. David Kotin and the staff of the Canadian History Department put up with five years of struggles and tribulations in coping with a new computer system which had not really been designed for the challenging problems we were forcing on it. Many colleagues, some of whom are in this room today, offered many helpful suggestions and were always willing to share their knowledge and expertise. Lastly, though really it ought by rights to be firstly, I must acknowledge Karen Evans, the co-compiler of the Bibliography. Her contribution to the work was enormous, and I can only say that should you be fortunate enough to find a collaborator of her quality you will indeed have been blessed.

It affords me special pleasure to accept this medal for a work that continues the first major bibliographical project in Marie Tremaine's career. Thank you. 